Article

\title{
Evaluation of Circular and Integration Potentials of Innovation Ecosystems for Industrial Sustainability
}

\author{
Tatyana Tolstykh ${ }^{1}$, Nadezhda Shmeleva ${ }^{2}$ (D) and Leyla Gamidullaeva ${ }^{3, *}$ \\ 1 Department of Industrial Management, National University of Science \& Technology (MISIS), \\ 119049 Moscow, Russia; tt400@mail.ru \\ 2 Department of Economics, National University of Science \& Technology (MISIS), 119049 Moscow, Russia; \\ nshmeleva@misis.ru \\ 3 Department of Management and Economic Security, Penza State University, 440026 Penza, Russia \\ * Correspondence: gamidullaeva@gmail.com; Tel.: +7-890-9317-3366
}

Received: 18 May 2020; Accepted: 2 June 2020; Published: 3 June 2020

check for updates

\begin{abstract}
The aim of this paper is to address the gap in the academic literature towards the development of methodological approaches to the industrial ecosystem potential assessment. This study is focused on the industrial ecosystems formed on the basis of a symbiotic model and implementing the principles of circularity. The article systematizes the problem of using circular and ecosystem approaches in industrial development. A contribution to the literature was achieved by providing a systemic perspective on the sustainable industrial process. In this paper, we develop the methodological foundations to improve the understanding of circular and integration processes' influence on the industrial ecosystem potential. For a relevant analysis of industrial ecosystem potential, the existing patterns of system functioning were taken into account, including entropy equilibrium and Harrington model. We illustrate our assumptions with an empirical case study of two different industrial ecosystems, Kalundborg Symbiosis and Baltic Industrial Symbiosis, with an assessment of their circular and integration potentials. The results highlight that the potential of Kalundborg Symbiosis in the field of circularity is realized quite productively, but not in full. The holistic knowledge of circularity process provides new information that supports academics, policymakers, government, and individuals with a more appropriate understanding of the conditions that help to eliminate the environmental problems faced in society, helping to achieve the country's sustainable development goals.
\end{abstract}

Keywords: industrial ecosystem; innovation ecosystem; innovation; circular economy; integration potential; industrial symbiosis; sustainability

\section{Introduction}

Over the last decade, the discourse on enhancing the sustainability of industrial development has focused on the circular economy model, and the idea to reshape the industrial systems following the objective of a more balanced interplay of environmental and economic systems has gained increased attention worldwide. Circular economy is widely considered as a strategy to reconcile industrial systems with the natural environment through the careful design of new products and implementing the "closed-loop system" processes [1]. Russian Federation is just starting to develop a circular and green economy [2]. Implementing the circular economy (CE) concept encourages environmental protection and social prosperity [3], eliminate the environmental problems faced by society, while enabling value-added growth of industries in line with country's sustainable development.

Amid the prolific studies on circular economy conducted by different schools of thought, is the relatively sparse research focusing on specific industrial ecosystems implementing the principles of circularity. The new development paradigm is changing business management approaches, behavioral 
strategies, and the speed of responses to external challenges. Under this circumstance, it becomes relevant to develop industrial ecosystems ensuring sustainable development and quick response to new technological transformations. At the same time, the integration is of substantial importance, when the various systems interact with each other and create value. This study is focused on the industrial ecosystems formed on the basis of a symbiotic model and implementing the principles of circularity. The article systematizes the problem of using circular and ecosystem approaches in industrial development. The authors propose a comprehensive three-level technique allowing evaluation of the integration and circular potentials of an industrial ecosystem through consistent assessment of the potentials of individual actors and groups of actors.

The remainder of this article is organized as follows. After this introduction, in Section 2, we provide a theoretical overview CE, related schools of thoughts, its principles, underlying concepts, and tools. Section 3 presents a new methodology for the evaluation of circular and integration potentials of industrial innovation ecosystems. With the aim of a relevant analysis of ecosystem potential, the existing patterns of system functioning were taken into account, including entropy equilibrium, and Harrington model. Section 4 is about the theoretical foundations of our research introducing the authors' conceptual assumptions and chosen approaches. Section 5 focuses on the implementation of the proposed methodological approach. We illustrate our assumptions with an empirical case study of two different industrial ecosystems, Kalundborg Symbiosis and Baltic Industrial Symbiosis, with an assessment of their circular and integration potentials. Section 6 highlights the key findings of the study and presents the theoretical contribution and practical significance of the study for the necessary improvement of the circular economy in Russia. Finally, in Section 7, some limitations of the research and future research perspectives are proposed.

\section{Literature Review}

Originally, CE aims to increase the efficiency of resource use, with a special focus on urban and industrial waste, to achieve a better balance and harmony between economy, environment, and society [4]. The understanding of circular economy is ambiguous among researchers today. Many studies argue the CE implications in managerial terms for business efficiency [5-7].

Meanwhile, "there is no single group with the undisputed authority to define what circular economy means exactly" [8]. Many studies show that the CE model traces different methodological approaches and that its origins seem to be mainly rooted in different fields [9]. The principles of CE are mainly gathered from other schools of thought, including industrial ecology [10,11], ecological economics [12,13], performance economy [14], natural capitalism [15], product-service systems [16], blue economy [17], etc. A deeper analysis of the approaches proposed by these schools of thought is presented in [18].

Our research interest lies with the concepts of symbiosis, ecosystems, and ecoparks as a single school of thought with the industrial ecology, focused on the creation of industrial ecosystems by using ecological principles [19-21]. These ecological principles can be successfully applied to different sectors, including energy, construction, agriculture, metallurgy, etc.

In addition, it is crucial to identify how CE and the concept of sustainability relate. As noted in [18], CE can contribute to the United Nations Sustainable Development Goals, including environmental, economic, and partly social dimensions of sustainability.

The term "ecosystem" is widely used in recent studies. Manufacturing companies increasingly generate and implement innovations in collaboration with various stakeholders in different types of innovation ecosystems. The most comprehensive definition of innovation ecosystem is that proposed by Granstrand and Holgersson (2020). According to the authors, such ecosystem is an evolving set of actors, activities, and artifacts, and the institutions and relations, including complementary and substitute relations, that are important for the innovative performance of an actor or a population of actors [22]. The researchers identify two conceptual approaches to the ecosystems [23]. The first approach identifies it as a group of actors interconnected through resources exchange and production 
cycle. According to the second approach, ecosystem is a system of interconnected technologies, cooperating and competing firms offering related goods and services [24,25].

In parallel, the theory of industrial ecosystems is actively evolving. Kleiner defines industrial ecosystems as localized socioeconomic formations achieving sustainable development through the circulation of resources in objective, environmental, process, and project subsystems [26]. In [23], industrial ecosystem is defined as a set of components made by the product platform's owner and enhancements made by independent companies from the periphery. In turn, the ecosystem platform is defined as a network of innovations, increasing the platform's value $[27,28]$.

Several terms related with the industrial ecosystems have appeared in the literature, stressing their interdisciplinary nature, including the industrial symbiosis, (eco-) industrial parks, and (eco-) industrial networks. We will further specify these notions.

Industrial symbiosis is a notion that originated from the industrial ecology field. It refers to an intercompany resource exchange network in which waste outflow of a company constitutes a recourse inflow for another [29]. Industrial symbiosis is often viewed as a sustainable development and circular economy tool $[30,31]$. Kalundborg Symbiosis is one of the most cited examples of industrial symbiotic relationships.

Eco-industrial network may include sporadic interactions and knowledge exchange interactions as well [32].

The term of eco-industrial parks appeared first in 1992 at the UN Conference on Environment and Development in Rio de Janeiro [33]. According to UNIDO definition, eco-industrial parks are production and service organizations located in close proximity, which achieve sustainable development through cooperative resource management and environmental impact handling [34].

Comparing to industrial parks, eco-industrial parks attain synergies of negative environmental impact mitigation and local living standards growth in line with economic benefits.

United States Environmental Protection Agency (EPA) [35] gives a definition of the industrial park as an association of goods and service providers aimed at improving economic and ecological performance by cooperative resources and environmental management. Burnside Industrial Park in Canada is a well-known example of an industrial park.

Initiatives to integrate technoparks and other innovation infrastructure objects into cooperation networks are taken by the EU, UNIDO, and other international organizations. We view eco-industrial parks as one of the key actors of industrial ecosystems based on circularity principles.

Researchers widely use term "industrial metabolism" referring to "the whole integrated collection of physical processes that convert raw materials and energy plus labor, into finished products and wastes in a (more or less) steady-state condition" [36]. Special tools are used within CE "to study the flows of matter, energy, and information that cross the industrial and natural systems, reflecting different levels of industrial metabolism" [37]. Considering the approaches exposed, we have to emphasize that there is a lack of practical tools for the assessment of ecosystem actors' symbiotic and circular interrelations leading to reconciling the economic and environmental sphere.

\section{Conceptual Framework}

Cooperation of ecosystem actors is based on network partnership principles and cognition as a principal mechanism for achieving strategic goals by the actors. Ecosystem operates at a basis of "energy" exchange between business, industry, scientific community, and government. By "energy" we mean information, knowledge, technologies, or key resources. Ecosystem self-organization occurs as a response to digital challenges, ecological and industrial trends in the forms of new innovation projects, products, digital platforms, and technologies, including recycling.

Ecosystem model is the evolution of cluster, network, and infrastructure communication models (Table 1). It brings together best cooperation practices with ecosystem-specific features crucial in terms of new technological challenges. 
Table 1. Comparison of different industrial cooperation models.

\begin{tabular}{|c|c|c|c|}
\hline Models of Industrial Cooperation & Cooperation Target & Matching Criteria & $\begin{array}{l}\text { Coordination } \\
\text { Mechanism }\end{array}$ \\
\hline Ecosystem & $\begin{array}{c}\text { Product or digital } \\
\text { innovation initiation and } \\
\text { implementation }\end{array}$ & $\begin{array}{l}\text { Life cycle stages of projects, } \\
\text { products, technologies and } \\
\text { circularity principles }\end{array}$ & Self-organization \\
\hline Industrial symbiosis & $\begin{array}{l}\text { Limited resources } \\
\text { usage optimization }\end{array}$ & $\begin{array}{l}\text { Complementarily of by-products } \\
\text { and inputs }\end{array}$ & Self-organization \\
\hline Cluster & $\begin{array}{l}\text { Maintaining industry's } \\
\text { or } \\
\text { regional competitiveness }\end{array}$ & Stages of the production process & $\begin{array}{l}\text { Federal and regional } \\
\text { management institutions }\end{array}$ \\
\hline Network & $\begin{array}{l}\text { Entrepreneurship } \\
\text { activity based on joined } \\
\text { resources and } \\
\text { advantages usage by } \\
\text { the participants }\end{array}$ & Production or service value chain & $\begin{array}{l}\text { Managed by the key } \\
\text { network participant }\end{array}$ \\
\hline Technopark & $\begin{array}{c}\text { Development and } \\
\text { commercialization of } \\
\text { innovation technologies }\end{array}$ & $\begin{array}{l}\text { Property complex with } \\
\text { administrative infrastructure }\end{array}$ & Managing company \\
\hline Industrial park & $\begin{array}{l}\text { Competitive } \\
\text { industrial production }\end{array}$ & $\begin{array}{l}\text { Industrial area with engineering } \\
\text { infrastructure suitable for new } \\
\text { production companies }\end{array}$ & Managing company \\
\hline Eco-industrial park & $\begin{array}{l}\text { Joint resources } \\
\text { management at a certain } \\
\text { territory to achieve } \\
\text { sustainable } \\
\text { socio-economic and } \\
\text { ecological development }\end{array}$ & $\begin{array}{l}\text { Geographic proximity and } \\
\text { technological complementarily }\end{array}$ & $\begin{array}{c}\text { Federal and regional } \\
\text { management institutions }\end{array}$ \\
\hline Eco-industrial network & $\begin{array}{l}\text { Resource efficiency } \\
\text { maintenance and } \\
\text { negative environmental } \\
\text { impact mitigation } \\
\text { through closing resource } \\
\text { loops at dispersed areas }\end{array}$ & $\begin{array}{c}\text { Cooperation of dispersed } \\
\text { infrastructure objects and } \\
\text { customers based on sophisticated } \\
\text { logistic network }\end{array}$ & $\begin{array}{l}\text { Key participant or a } \\
\text { managing company }\end{array}$ \\
\hline Special economic zone & $\begin{array}{l}\text { Hi-tech, import } \\
\text { substitution and tourism } \\
\text { industries development }\end{array}$ & $\begin{array}{l}\text { Based on special conditions for } \\
\text { entrepreneurship activity }\end{array}$ & $\begin{array}{c}\text { Managing company with } \\
\text { the state as the } \\
\text { sole shareholder }\end{array}$ \\
\hline
\end{tabular}

Self-organization, lack of managerial institutions, and intellectual environment are the basic differences between the industrial ecosystem and clusters or networks.

However, self-organization does not suppose chaotic and spontaneous integration. "Pacemaker" is the center of the ecosystem that coordinates and balancing actions of all other actors. An actor, technology, project, or platform may act as a "pacemaker".

Actors of the industrial ecosystem include industrial companies, technoparks, start-ups, venture funds, engineering companies, government institutions, funds, and financial structures and other actors whose interests overlap with the strategic goals of the ecosystem, which are defined by the pacemaker.

In terms of the new industrial revolution, we may highlight the following principles for industrial ecosystems establishment:

- transboundary ecosystem processes;

- $\quad$ self-organization, self-regulation, and self-development;

- joint development and use of information, innovation, and intellectual resources;

- continuous flow of successive projects (one project initiates the following projects' implementation);

- agility and flexibility to external challenges;

- project- and client-orientation;

- diversity of actors and network organization design;

- collaboration based on partnership, trust, cooperation, and mutual help;

- balance between goals and objectives of actors;

- knowledge circulation; 
- resources conservation priority;

- maintaining and development of each actor's potential;

- circularity principles enabling to extend the life cycle of resources and to regenerate them for use in other projects.

The ecosystem is constantly changing depending on the life cycles of its projects. Actors are, therefore, not static and may fulfill different roles in different projects. The life cycles of the projects under the ecosystem's implementation imply the following "set" of actors and roles (Figure 1):

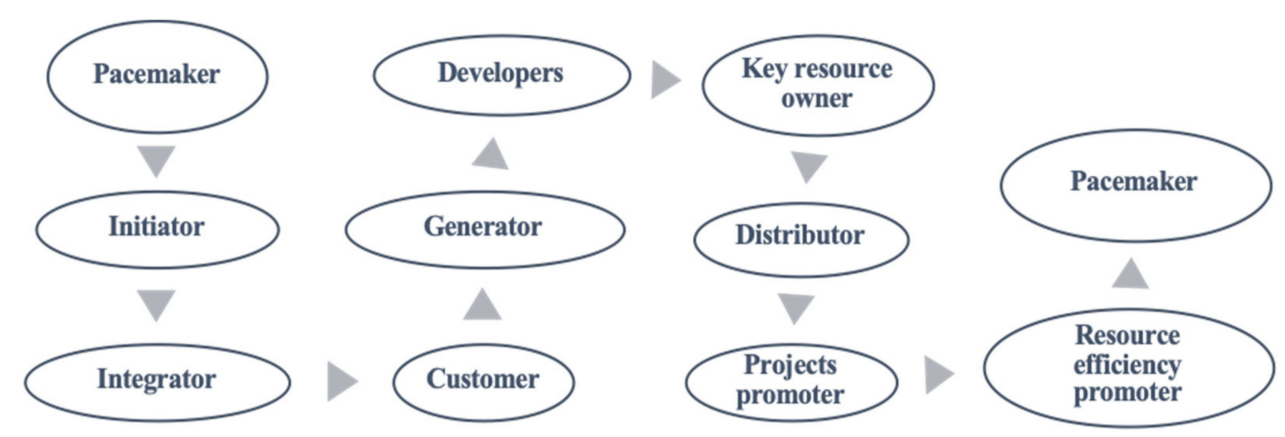

Figure 1. Roles of the ecosystem's actors depending on the project's life cycle. Source: Own elaboration.

For instance, complex industrial objects that need to transform can initiate or create demand for substantial innovative projects. Universities that accumulate and create national and worldwide expertise and cooperate with many companies from the industry can act as integrators involving new actors and enabling collaboration, as well as knowledge and information exchange. An integrator also acts as a pacemaker and a project office. When new members are involved and knowledge is being exchanged, actors start to generate ideas and initiate projects. That provides the principle that ecosystem projects have no time limits. At the project generation stage (construction, logical, and technical elaboration, ideas formalization), technoparks, venture companies, research centers, etc., act as initiators, integrators, and generators. At the implementation stage, other industrial companies, startups, and engineering companies are involved. They act as developers and suppliers and organize themselves in project teams. Industrial companies, together with the actors involved in the project development, operate as distributors implementing the project within industrial systems. The next stage is the promotion of successful projects, where promoters, such as universities, industrial companies, industrial exhibitions, and marketing companies, transform experience into new projects. Actors that promote energy efficiency focus on implementing principles of circular economy and promote circularity in projects.

We define sustainable development of an industrial ecosystem as technological, innovation, and economic transformations fostering production and innovation potential development of all its actors and system as a whole through balancing digital transformation and circularity with human capital and technological development.

Circularity is a modern trend in economic processes assessment. The circular economy model aims to keep products, components, and materials at their highest utility and value at all times, distinguishing between technical and biological cycles [38].

OECD introduced the business models for circular economy based on the revision of relations between the actors [31]. Various combinations might be appropriate for a production system depending on its specificities. Cooperation between industrial companies enables joint resources management to achieve resource efficiency and waste minimization. Cooperation with consumers makes possible closing loops for resources, which would have become waste within linear economy paradigm. Sharing consumption platforms optimizes demand for goods and free resources while improving quality of life. Regulators' and knowledge institutions' participation in production cycles enables new technologies and potential partnership identification. Therefore, industrial ecosystems develop around joint resource 
management by all stakeholders and adopt circularity principles. This contributes to effective resource management and sustainable ecosystem development.

Competitiveness and integration of potential growth of actors are key targets of industrial ecosystems. Therefore, an integrated assessment of all ecosystems' component potentials may serve as an indicator for its sustainable development (Figures 2 and 3).

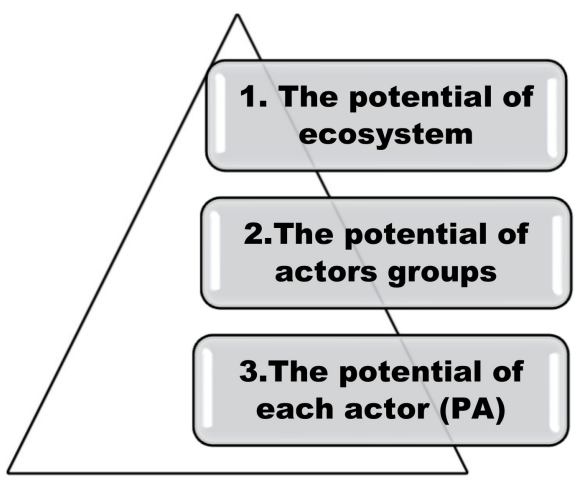

Figure 2. Generalized structure of ecosystem potentials. Source: Own elaboration.

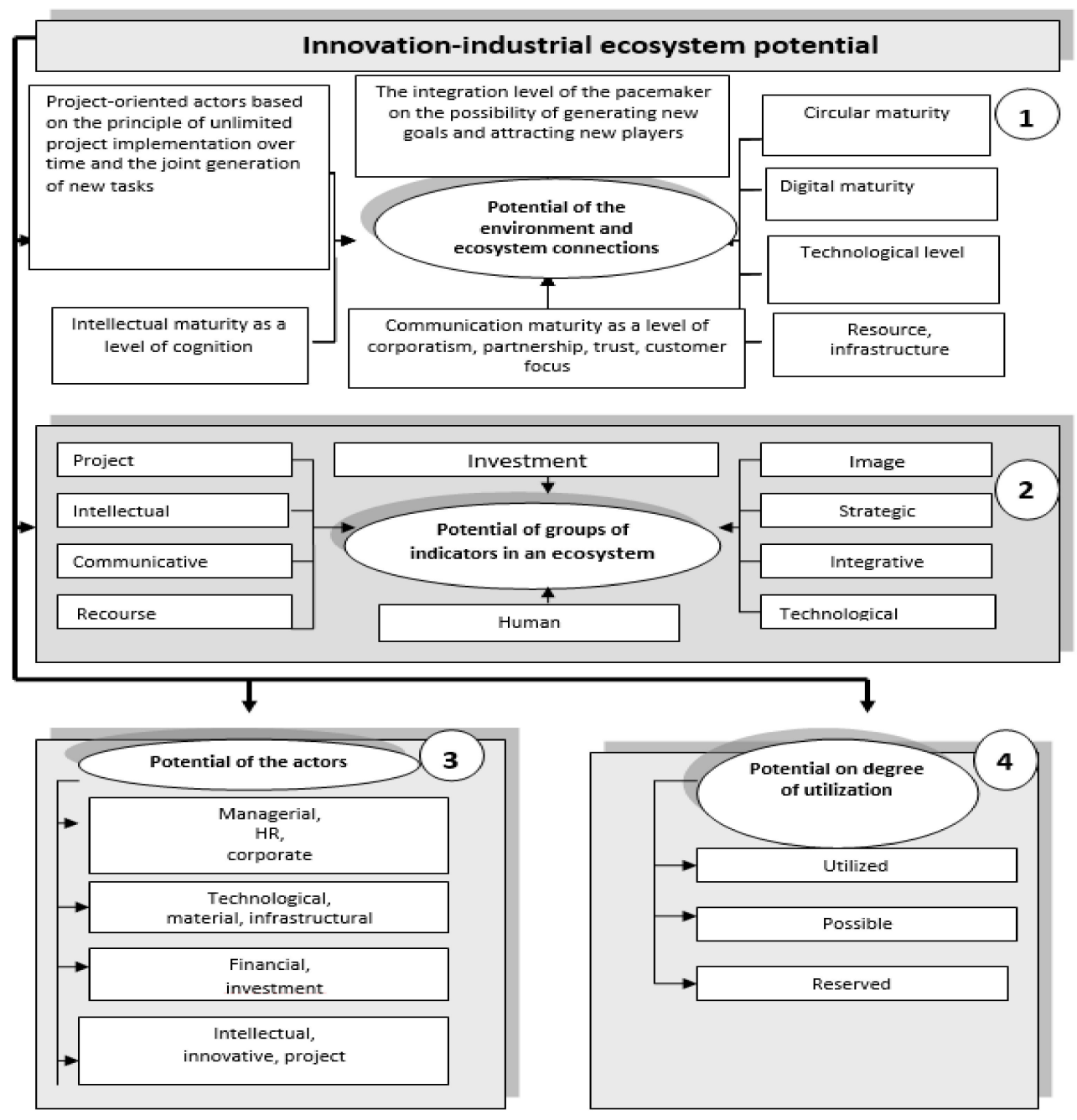

Figure 3. The potential structure of the industrial ecosystem. Source: Own elaboration. 
We define an ecosystem's potential as a set of sources, opportunities, and means to reach its goals. Potentials may be classified by types and groups depending on the resources forming these potentials. For instance, material resources form economic potential consisting of resource, production, and investment potentials. Actors are engaged in activities in which prospects depend on the respective innovation, intellectual, and project potentials. Despite their diversity, potentials have the following properties:

- potentials are the results of the resources' interaction within a system, therefore, similar sets of resources form different potentials depending on ecosystem profile;

- potential evaluation and interpretation depend on goals and objectives to which this potential refers;

- potential is an aggregated resource consisting of tangible and intangible components.

We also introduce a new term "circular potential" and define it as aggregated resources aimed to keep products, components, and materials at their highest utility and value at all times, distinguishing between technical and biological cycles. It is worth noticing that in the international practice, balanced score indicators are used to evaluate cyclic processes-Recycling Potential Index (RPI) and Waste Generation Index (WGI). However, these indicators allow evaluating only the efficiency of processing certain types of waste and materials or the level of circularity.

\section{Research Methodology}

To assess the compliance of the actual results of the activity of actors in the industrial ecosystem with the target settings, it is possible to use an integral indicator calculated on the basis of the proposed scales for assessing preference indicators (Figure 2).

At the lower, third, level of the hierarchy, the potential of each actor (PA) is evaluated depending on its role in the ecosystem. The potential of actor i can be represented by an integral quantity, including components:

$$
P_{3 i}=f\left(G_{1 i}, G_{2 i}, G_{3 i}, G_{4 i}, G_{5 i}, G_{6 i}, G_{7 i}, G_{8 i}\right), i=1 \ldots n
$$

where $n$-number of actors in the ecosystem, $\mathrm{G}_{1 \mathrm{i}}$ - production potential, $\mathrm{G}_{2 \mathrm{i}}$-innovation potential, $\mathrm{G}_{3 \mathrm{i}}$-intellectual potential, $\mathrm{G}_{4 \mathrm{i}}$ - human potential, $\mathrm{G}_{5 \mathrm{i}}$-financial potential, $\mathrm{G}_{6 \mathrm{i}}$-technological potential, $\mathrm{G}_{7 \mathrm{i}}$-project potential, $\mathrm{G}_{8 \mathrm{i}}$-resource potential, $\mathrm{G}_{9 \mathrm{i}}$-managerial potential.

At the second level, the level of groups of actors, the integral potential can be represented as a function of the following subsystems:

$$
P_{2 j}=f\left(Q_{1 j}, Q_{2 j}, Q_{3 j}, Q_{4 j}, Q_{5 j}, Q_{6 j}, Q_{7 j}, Q_{8 j}, Q_{9 j}\right), j=1 \ldots m
$$

where $\mathrm{m}$-number of groups of actors in the ecosystem, $\mathrm{Q}_{1 \mathrm{i}}$-image, $\mathrm{Q}_{2 \mathrm{j}}$-strategic potential, $Q_{3 j}$-intellectual potential, $Q_{4 j}$-communication potential, $Q_{5 j}$-investment potential, $\mathrm{Q}_{6 \mathrm{j}}$-technological potential, $\mathrm{Q}_{7 \mathrm{j}}$ - project potential, $\mathrm{Q}_{8 \mathrm{j}}$-resource potential, $\mathrm{Q}_{9 \mathrm{i}}$-integrative potential.

Finally, the first level of the hierarchy is the level of indicators of the ecosystem as a whole, through indicators to assess the sustainability of development. This range of indicators is determined expertly, depending on the ecosystem's target settings (Figure 3).

Indicators of the lower level characterizing the potential of the actor are called an elementary group. Each elementary group has its own weight, $d_{j}^{1}$ in integral assessment. Elementary groups (first-order groups) in accordance with the hierarchical model are combined into second-order groups in accordance with the roles of actors in the ecosystems, each of which has its own weight, $d_{j}{ }^{2}$.

We introduce the notation.

For the elementary group:

$\mathrm{C}_{\mathrm{i}}$-target indicator values characterizing PA;

$\mathrm{f}_{\mathrm{i}}$-actually achieved indicator value; 
$d_{\mathrm{i}}$-weight (importance level) of the indicator;

$\mathrm{i}$-index of the indicator in a group, $\mathrm{i}=1 \ldots \mathrm{n}$.

For the groups:

$\mathrm{k}$-index of the project being implemented in an ecosystem;

$j$-group index for the $k$-th project;

$d_{j}^{k}$-j-th group weight for the $k$-th project;

$F_{j}{ }^{\mathrm{k}}$-integral assessment of indicators for the $k$-th project from a group.

Thus, we set the following tasks:

1. To assess indicators in each elementary group.

To solve this problem, the following scale for evaluating indicators of the target value is proposed (Table 2). If the indicator is quantitative, then gradations can be determined through relative (or absolute) deviations, i.e., as $\left(c_{i}-f_{i}\right)$ or $\left(f_{i} / c_{i}\right)$.

Table 2. Scale of estimates of indicators of the elementary group.

\begin{tabular}{ccc}
\hline Evaluation $\mathbf{f}_{\mathbf{i}}$, Mark & Definition & Comments \\
\hline 1 & Absolute lag & The lag is undeniable \\
2 & Significant lag & The lag is explicit \\
4 & Average lag & The lag has practical confirmation \\
5 & Low lag & The lag is confirmed by indirect factors \\
6 & Equal to the targeted value & \\
7 & Weak dominance & Dominance is confirmed by indirect factors \\
8 & Average dominance & The dominance has practical confirmation \\
9 & Significant dominance & The dominance is explicit \\
& Absolute dominance & The dominance is undeniable \\
\hline
\end{tabular}

2. To determine the weights of the estimates in the elementary group and the weights of the groups for all projects, starting with the elementary.

Tasks may be solved by pairwise comparisons. The application of the method assumes the presence of the so-called matrix of pairwise comparisons A:

$$
A=\left(\begin{array}{cccc}
a_{11} & a_{12} & \ldots & a_{1 n} \\
a_{21} & a_{22} & \ldots & a_{2 n} \\
\ldots & \ldots & \ldots & \ldots \\
a_{n 1} & a_{n 2} & \ldots & a_{n n}
\end{array}\right)
$$

An arbitrary element of the matrix (3) $a_{i j}$-is a positive number showing "how many times" the index $\mathrm{i}$ (in the row) exceeds the index $\mathrm{j}$ (in the column). i.e., here the value of the element $a_{i j}$ is the value of preference in points of one indicator over another. To establish the values of $a_{i j}$, we will use the preference rating scale (Table 3).

Moreover, the matrix A in the ideal case should satisfy the following properties:

(1) the matrix is inversely symmetric, i.e.,: $a_{j i}=1 / a_{i j}$

(2) the matrix is consistent, i.e.,: $a_{i j}=a_{i k} \cdot a_{k j}$.

In this case, the maximum eigenvalue of the matrix $\mathrm{A}$ is equal to its order $n$ (the remaining eigenvalues are zero), and the corresponding eigenvector is a vector of weights of objects.

$$
\bar{y}=\left(y_{1}, y_{2}, \ldots, y_{n}\right), i=\overline{1, n}
$$


It should be noted that the eigenvector (4) is not normalized, and this property must be satisfied for the weights of the compared objects. Normalized weights can be calculated using the formula:

$$
d_{i}=\frac{y_{i}}{\sum_{i=1}^{n} y_{i}}, i=\overline{1, n}
$$

Then the sum of the weights will be equal to 1 .

Table 3. Preference rating scale.

\begin{tabular}{|c|c|c|}
\hline Evaluation $a_{i j}$, Mark & Definition & Comments \\
\hline 1 & Absolute lag & $\begin{array}{l}\text { Indicator } i \text { (in the line) is equally significant } \\
\text { with the indicator } j \text { (in the column) }\end{array}$ \\
\hline 2 & Significant lag & Intermediate value \\
\hline 3 & Average lag & Indicator $i$ slightly preferable than indicator $j$ \\
\hline 4 & Low lag & Intermediate value \\
\hline 5 & Equal to the targeted value & Indicator $i$ clearly preferable than indicator $\mathrm{j}$ \\
\hline 6 & Weak dominance & Intermediate value \\
\hline 7 & Average dominance & $\begin{array}{c}\text { The superiority of indicator } i \text { over indicator } j \\
\text { has practical confirmation }\end{array}$ \\
\hline 8 & Significant dominance & Intermediate value \\
\hline 9 & Absolute dominance & Indicator $i$ undeniably exceeds indicator $j$ \\
\hline
\end{tabular}

3. To determine the integral estimate of the $P A$.

The integral PA score is defined as the geometric weighted average of the group score estimates, i.e.,

$$
F_{j}^{1}=\prod_{i} f_{i}^{d_{i}}
$$

4. To determine the integral indicator of $k$-th level groups.

Similarly to Formula (4), for groups of the $k$-th level we have:

$$
F_{j}^{k}=\prod_{i} F_{i}{ }^{d_{i}}
$$

i.e., weighted geometric mean of subgroups of $j$-th group.

5. To identify the potential for sustainable ecosystem development.

The integral indicator of IEP (industrial ecosystem potential) is defined as an indicator of the group of the highest level of the hierarchy, according to Formula (7). Thus, in the integral indicator, we can use both qualitative and quantitative estimates characterizing the effectiveness of the processes occurring in the ecosystem.

A qualitative assessment of the ecosystem potential should be carried out by experts based on the significance of each component. To quantify the potentials of ecosystem actors, the authors propose the use of groups of integrated indicators in accordance with the ecosystem structure shown in Figure 4.

A comprehensive literature review indicates that most publications provide examples of the separate potentials' compilation for various ecosystems. For example, Hatziiordanou, et al. [39] give the examples of the natural potential assessing for biological ecosystems based on the guidelines of the European Environment Agency and European Commission Research Center [40]. For regional ecosystems [41-43], the innovative and investment potentials are mainly evaluated. Kim and Bae [5] provide an example of assessing the circulating potential of automobile vehicles for the automobile concern. Some authors have attempted to assess the potential of clusters using integral indicators, 
rather than individual types of potentials. In the paper [44], an example of assessing the potential of a textile cluster was given.

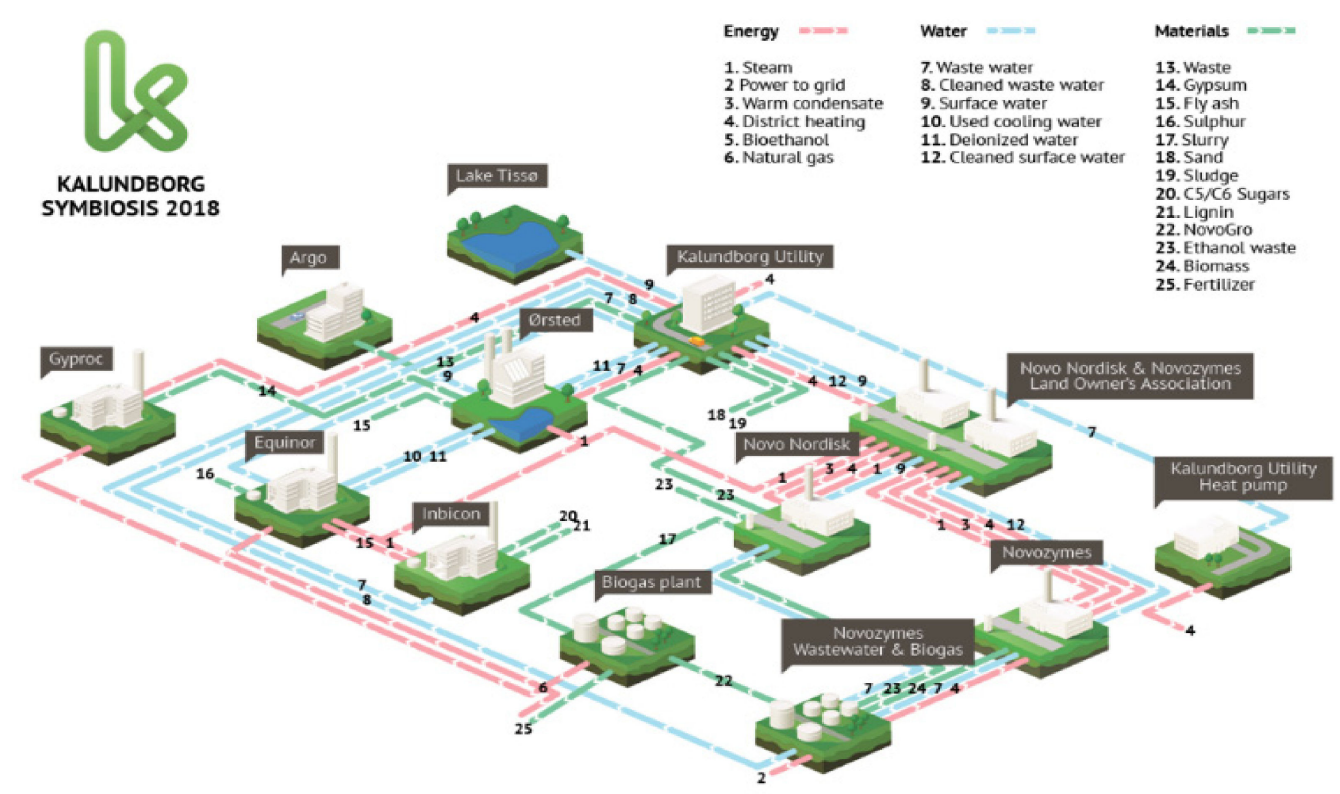

Figure 4. Interaction of actors in the Kallunborg industrial ecosystem. Source: https://www. ellenmacarthurfoundation.org/case-studies/effective-industrial-symbiosis

When forming a group of integrated indicators, the authors of the article proceeded from the definition of an ecosystem and the principles of its functioning, the circularity of resources and ecosystem sustainability. The set of indicators in each group may vary depending on the objectives of the assessment, types of projects, time intervals and other factors. The interpretation of the results of the potentials' assessment depends on the goals and objectives of the projects for which they are considered.

Table 4 shows examples of possible integral indicators for assessing the potentials of actors, reflecting their contribution to the development of the ecosystem and groups of actors. The potential of the ecosystem as a whole can be assessed through the sustainability of its development.

When assessing the ecosystem actors' potentials, an integrated criterion, the potential for the first and second levels of the hierarchy, is determined as the integrating result of indicators of the third hierarchy level (elementary group).

Moreover, there are certain requirements for the formation of an integral criterion through a hierarchy of indicators:

1. The integral criterion should allow evaluating the final results of the efficiency of the processes.

2. The integral criterion should allow presenting it in the form of a hierarchy (pyramid) of local criteria, which, as a result, form an integral system of criteria.

3. The structure of the integral criterion should be invariant, covering several levels simultaneously.

The advantage of the proposed method for assessing the ecosystem actors' potentials is that the results obtained can be comparable in dynamics at different levels of the ecosystem and with other ecosystems. In addition, the data obtained can be combined with other indicators for further comprehensive analysis.

Basically, the proposed method allows joint assessment of all types of potentials of an ecosystem at three levels (actors, groups of actors, and the ecosystem as a whole). Meanwhile, the potential of an ecosystem is influenced by the interconnections between actors and groups of actors. Therefore, the lack of separate assessment of potentials of individual actors does not affect the reliability of the whole ecosystem potential calculations results. It seems problematic to demonstrate complete calculations for 
each ecosystem level within one article, mainly due to its volume limitation. Furthermore, the industrial ecosystems presented in the case studies below are at various phases of the life cycle, thereby, it does not allow calculating all types of potentials for one ecosystem. For example, the «Baltic Symbiosis» ecosystem is at the "birth" phase. Accordingly, baseline data on reducing CO2 emissions and resource consumption are not available to measure its circular potential.

Table 4. Indicators for assessing the potential of ecosystem actors.

\begin{tabular}{|c|c|c|}
\hline Potential Type & Integral Indicators & Quantitative/Expert \\
\hline \multicolumn{3}{|c|}{ Indicators for Assessing the Potential of Actors in the Ecosystem } \\
\hline Technological potential & $\begin{array}{l}\text { 1. The coefficient of technological exchange (the ratio of income and payments } \\
\text { in the circulation of technology and R\&D results) } \\
\text { 2. Technology update rate } \\
\text { 3. The share of unique technologies in the overall structure } \\
\text { 4. The level of information and communication support }\end{array}$ & $\begin{array}{l}+/- \\
+/- \\
+/+ \\
-/+\end{array}$ \\
\hline Innovative potential & $\begin{array}{l}\text { 1. Total Innovation Index SII } \\
\text { 2. The innovative activity of the actor (the number of innovations introduced } \\
\text { per unit time/activity level) } \\
\text { 3. Digital Maturity Level } \\
\text { 4. The proportion of the uniqueness of the products } \\
\text { 5. Research and development costs } \\
\text { 6. Innovation and project level (the number of innovative projects to the total } \\
\text { number of ongoing projects) }\end{array}$ & $\begin{array}{l}+/- \\
+/+ \\
+/+ \\
+/- \\
-/+ \\
+/-\end{array}$ \\
\hline HR potential & $\begin{array}{l}\text { 1. The level of managerial maturity } \\
\text { 2. The level of digital maturity of staff } \\
\text { 3. The level of maturity of project management } \\
\text { 4. The level of competency uniqueness (the number of employees with unique } \\
\text { competencies to the total number of personnel). }\end{array}$ & $\begin{array}{l}-/+ \\
-/+ \\
+/+ \\
+/-\end{array}$ \\
\hline Financial potential & $\begin{array}{l}\text { 1. Balanced financial result of the actor } \\
\text { 2. Return on total assets } \\
\text { 3. The level of financial leverage }\end{array}$ & $\begin{array}{l}+/- \\
+/- \\
+/-\end{array}$ \\
\hline Strategic potential & $\begin{array}{l}\text { 1. Correspondence of resources to the strategic goals of the actor } \\
\text { 2. Index of actor satisfaction with environmental quality } \\
\text { 3. The level of corporate culture }\end{array}$ & $\begin{array}{l}-/+ \\
-/+ \\
-/+\end{array}$ \\
\hline Circular potential & $\begin{array}{l}\text { 1. Reduced energy consumption } \\
\text { 2. Saved resources } \\
\text { 3. Reduced } \mathrm{CO}_{2} \text { emissions }\end{array}$ & $+/+$ \\
\hline \multicolumn{3}{|c|}{ Indicators for Assessing the Potential of Actor Groups in An Ecosystem } \\
\hline Intellectual & $\begin{array}{l}\text { Integral indicator, which includes intellectual assets, unique technologies, } \\
\text { percentage of submitted ideas. }\end{array}$ & $+/+$ \\
\hline Integrative & $\begin{array}{l}\text { 1. The level of cooperation between actors (cooperation) } \\
\text { 2. Transfer of knowledge, technology, results within the ecosystem } \\
\text { 3. The number and cost of joint projects in which ecosystem actors are involved. }\end{array}$ & $\begin{array}{l}-/+ \\
+/- \\
+/-\end{array}$ \\
\hline
\end{tabular}

\section{Results}

Empirical Case Studies from Industrial Ecosystems "Kalundborg Symbiosis" and "Baltic Industrial Symbiosis"

Kalundborg Symbiosis is the first industrial ecosystem in the world that works on the basis of a symbiotic model and implements the principle of circularity, consisting in the fact that the waste of one actor becomes resources for others. The introduction of industrial symbiosis as a model of sustainable development and an instrument of a circular economy allowed the Kalundborg industrial ecosystem to reduce annual $\mathrm{CO}_{2}$ emissions by 635 tons, water consumption by $3.6 \mathrm{~m}^{3}$ and energy by $100 \mathrm{GWh}$, which amounted to 24 million Euros in value terms [45,46].

Kallunborg Symbiosis appeared as a result of interactions between actors around key resources -water, energy, materials. The actors in the Kalundborg ecosystem are 12 public and private companies linked by a network of material and energy flows (Figure 4).

One of Kalundborg's strategic goals is to fully utilize the resource flows within the production loop. It is planned to implement 10 projects aimed at optimizing and closing resource chains by 2025 . Major projects related to the transition to green energy [47].

Project $1\left(P_{1}\right)$ : Obtaining energy from biomass (wood chips) to replace coal energy.

Project $2\left(P_{2}\right)$ : Extraction of biogas from by-products and wastewater.

Project $3\left(P_{3}\right)$ : Abandonment of the principle of power supply by the principle of marginality. 
With this approach, to obtain additional capacity, the cheapest source of energy is used at current loads.

Three ecosystem's actors are involved in the implementation of projects for the transition to green energy: Asnæs power station $\left(A_{1}\right)$, Kalundborg Bioenergi $\left(A_{2}\right)$, Orsted $\left(A_{3}\right)$ [20].

To assess the circular potential of the Kalundborg Symbiosis industrial ecosystem through the potentials of actors implementing joint projects, the authors propose using a group of indicators related to resource efficiency and reducing the environmental burden on the environment. Based on possible models for the implementation of the circularity principle proposed by OECD, it is advisable to use the following indicators to assess the circular potential of an ecosystem: Reduced resource, energy, and $\mathrm{CO}_{2}$ emissions.

The initial data for calculating the circular potential of the Kalundborg ecosystem are presented in Table 5. To convert the quantitative values of the indicators to points on a dimensionless ten-point scale that is common for all parameters of the assessment model, the Harrington desirability function was applied [19]. The desirability scale establishes a correspondence between a numerical and an empirical system of preferences.

Table 5. Initial data for calculating the circular potential of the ecosystem for 2019.

\begin{tabular}{lccc}
\hline \multicolumn{1}{c}{ Indicators } & Actor 1 & Actor 2 & Actor 3 \\
\hline 1. Reducing $\mathrm{CO}_{2}$ emissions, tons & 685,543 & 18,773 & 5150 \\
2. Reducing energy consumption, $(\mathrm{MWh})$ & 6506 & 82,888 & 0 \\
3. Saving resources, tons & $-79,880$ & 0 & 0 \\
\hline
\end{tabular}

In accordance with the Harrington methodology, the lower limit of indicator value admissibility is the reduction of $\mathrm{CO}_{2}$ emissions as 0 (one-sided restriction). Then, on the scale of desirability, this limit corresponds to $d=0.37$. The value of this indicator, equal to one million tons, is "very good," that is, on the scale of desirability, it corresponds to $0.8(d=0.8)$. Then, using Formulas $(4)$ and (5), the coded values of these control points $\left(y_{i j}\right)$ and the coded value of the desired parameter were calculated.

$$
\begin{gathered}
y^{\prime}(1)=-\ln \ln (1 / 0.37)=0.00576 \\
y^{\prime}(10)=-\ln \ln (1 / 0.8)=1.4999
\end{gathered}
$$

The equation $y^{\prime}=a \cdot y+b$ acts as a mechanism for transition $y$ в $y^{\prime}$. The value of " $a$ " and " $b$ " can be found through a system of equations.

$$
\begin{aligned}
& 0.00576=a \cdot 1+b \\
& 1.4999=a \cdot 10+b
\end{aligned}
$$

Therefore, $a=0.16576$ and $b=-0.16025$.

Define the coded value of the parameter $\mathrm{CO}_{2}$ emissions reduction. When $y=0, y_{i j}=0.37$, and the level of desirability is $d=0.69$. In a similar way, indicators were evaluated for other actors. The calculation results are given in Table 6 . The resulting indicator for assessing the ecosystem's circular potential $\left(F_{c}\right)$ is recommended to be defined as the geometric mean of three components: reduction of $\mathrm{CO}_{2}$ emissions and energy consumption, resource-saving (Formula (6)).

The circulation potential of the ecosystem calculated according to Formula (7), was $F_{c}=0.575$.

Diagnostic results for three components, as well as a general assessment, are determined in points on a scale whose boundary marks are 0 and 1 . The closer the actor's potential rating to 1 , the better this participant for the ecosystem from the position of all the potential building components. The value of the actors potential in the range from 0 to 1 correspond to the level on the Harrington scale of "very bad" (0.2-0); from 1 to 2-"bad" (0.37-0.20); from 2 to 3- "satisfactory" (0.63-0.37); from 3 to 4 - "good" (0.80-0.63); from 4 to 5-“very good" (1.00-0.80). 
According to the Harrington scale, the potentials of the actors Asnæs (0.51) and Orsted (0.55) are classified as "satisfactory", and the potential of the actor Kalundborg Bioenergi (0.68) is classified as "good".

Table 6. Interpretation of standard marks on the Harrington scale for assessing the circular potential of ecosystem actors.

\begin{tabular}{|c|c|c|c|c|c|c|c|}
\hline \multirow[t]{2}{*}{ Actors } & \multicolumn{2}{|c|}{$\begin{array}{c}\text { Reducing } \mathrm{CO}_{2} \\
\text { Emissions, Tons }\end{array}$} & \multicolumn{2}{|c|}{$\begin{array}{c}\text { Reducing Energy } \\
\text { Consumption, (MWh) }\end{array}$} & \multicolumn{2}{|c|}{ Saving Resources, Tons } & \multirow{2}{*}{$\begin{array}{c}\text { Circular } \\
\text { Potential }\left(F_{c}\right)\end{array}$} \\
\hline & $y_{i j}$ & $d_{1}$ & $y_{i j}$ & $d_{2}$ & $y_{i j}$ & $d_{3}$ & \\
\hline $\mathrm{A}_{1}$ & 0.37 & 0.69 & -0.71 & 0.49 & -0.92 & 0.40 & 0.51 \\
\hline $\mathrm{A}_{2}$ & -0.96 & 0.38 & 0.20 & 0.82 & 0.00 & 1.00 & 0.68 \\
\hline $\mathrm{A}_{3}$ & -0.99 & 0.37 & -0.79 & 0.45 & 0.00 & 1.00 & 0.55 \\
\hline
\end{tabular}

The circular potential of the industrial ecosystem "Kalundborg Symbiosis" is realized quite productively, but supposedly, not in full. For example, the actor Asnæs is one of the key participants in the ecosystem around whose resources (energy, steam, and by-products) exchange relationships were formed. In accordance with the EU policy on reducing greenhouse gas emissions and finance the environmental projects, the potential of this actor must be evaluated primarily from a strategic perspective. From a managerial point of view, it is advisable for actors to continue working on joint circular projects, improving joint business processes, introducing new technologies, and thereby, strengthening symbiotic ties within the ecosystem.

The Kalundborg Symbiosis industrial ecosystem initiated a global project to create the Baltic Industrial Symbiosis (BIS) industrial ecosystem under the 2014-2020 Interreg Baltic Sea Region program, which brought together the European Union and Russia to develop innovative, transport and environmental potentials of the Baltic region [48,49]. Later, Kalundborg Symbiosis developed the concept and platform for BIS.

Ecosystem pacemaker-Tyreman Group implements the activities of the Baltic Industrial Symbiosis project in Russia and forms an ecosystem of manufacturing companies interested in symbiosis through the Symbiosis Center in St. Petersburg [50]. The main Russian actors in BIS are the Mineral State Unitary Enterprise, the St. Petersburg cluster of clean technologies for the urban environment, and the "Northern Shrimp». This large-scale program is being implemented in two phases of 2014-2020 and 2021-2027 years.

The objectives of the program second phase:

- Formation of potentials for the development of industrial enterprises.

- Growth of potentials among practitioners of industrial symbiosis in taking advantages of ecosystem collaboration.

- Formation of new business opportunities during the implementation of the program.

- Acceleration of business development based on circular and ecosystem approaches.

To assess the integration potential of the BIS program second stage $\mathrm{o}$, the authors applied an assessment model based on the Harrington methodology. As the initial data, the quantitative indicators listed in Table 7 are used. To transfer the quantitative value of the integration activities' results into points on a dimensionless ten-point scale that is common to all parameters of the assessment model, the Harrington desirability function was used.

Table 7. The data for calculating the integration potential of Baltic Industrial Symbiosis (BIS).

\begin{tabular}{ccccc}
\hline Indicators & Western Europe & Eastern Europe & Northern Europe & Russia \\
\hline The cost of joint projects, in mln euros & 263.8 & 8.8 & 6.0 & 4.4 \\
The amount of co-financing, up to $\%$ & 75 & 85 & 50 & 70 \\
Number of joint projects & 10 & 7 & 5 & 3 \\
\hline
\end{tabular}


Evaluation of the ecosystem's integration potential was carried out on the basis of Formulas (6) and (7). The results are presented in Table 8.

Table 8. Interpretation of standard marks on the Harrington scale for assessing the integration potential of the ecosystem.

\begin{tabular}{cccccccc}
\hline Actors & \multicolumn{2}{c}{$\begin{array}{c}\text { Number of } \\
\text { Joint Projects }\end{array}$} & \multicolumn{2}{c}{$\begin{array}{c}\text { The Cost of } \\
\text { Joint Projects }\end{array}$} & \multicolumn{2}{c}{$\begin{array}{c}\text { The Amount of } \\
\text { Co-Financing }\end{array}$} & $\begin{array}{c}\text { Harrington's } \\
\text { Desirability Function }\end{array}$ \\
\cline { 2 - 6 } & $\boldsymbol{y}_{i j}$ & $\boldsymbol{d}_{\mathbf{1}}$ & $\boldsymbol{y}_{i j}$ & $\boldsymbol{d}_{\mathbf{2}}$ & $\boldsymbol{y}_{\boldsymbol{i j}}$ & $\boldsymbol{d}_{\mathbf{3}}$ & \\
\hline WE & 1.497 & 0.80 & 4.36 & 0.98 & -0.04 & 0.41 & 0.69 \\
$\mathrm{EU}$ & 1.000 & 0.69 & 1.30 & 0.76 & -0.02 & 0.45 & 0.63 \\
NU & 0.669 & 0.60 & 0.83 & 0.65 & -0.08 & 0.34 & 0.51 \\
Russia & 0.337 & 0.48 & 0.01 & 0.56 & -0.03 & 0.38 & 0.47 \\
\hline
\end{tabular}

Diagnostic results for three components, as well as a general assessment, are determined in points on a scale whose boundary marks are 0 and 1 . The closer the actor's potential rating is to 1 , the better this participant is for the ecosystem from the position of all the potential building components. According to the Harrington scale, the integration potentials of actors Western Europe (0.69) and Eastern Europe (0.63) are classified as "good". The values of the integration potentials of Northern Europe (0.51) and Russia (0.47) correspond to the "satisfactory" category. The integration potential of the ecosystem calculated by Formula (7) is $F_{i}=0.61$.

It is necessary to enhance the integration potential of actors by increasing the number of international cross-sectoral projects involving new ecosystem participants, increasing the volume of projects co-financing and strengthening international ties between ecosystem actors. Finally, this will lead to an increase in the integration potential of the ecosystem.

\section{Discussion and Conclusions}

In the modern world, the role of integration processes is growing, and the importance of assessing integration effects and potential is increasing both at the macro- and microlevels. The analysis of international publications on the integration potentials' assessment of regions, territories, clusters and ecosystems made it possible to identify the following methods: Simple indicators, gravity models, models of cross-industry balance, equilibrium models, general equilibrium models. However, one of the most commonly used tools is the gravity model (CGE), as these models can be easily modified for a specific task. The choice of our method is determined by the availability and specificity of the data, duration of networking, the level of development, and other factors. Another advantage of the proposed tool is the ability to track the multiplicative effect on ecosystem parameters after changing any exogenous indicator.

To assess the compliance of the actual results of the activities of the actors of the industrial ecosystem with the target settings, an integral parameter was calculated based on the proposed groups of indicators. Methodological approaches to assessing ecosystem potentials are based on the laws of ecosystem functioning, including entropy equilibrium, and Harrington's scale of preference.

We provided the empirical case study of two different industrial ecosystems, Kalundborg Symbiosis and Baltic Industrial Symbiosis. Based on the calculated indicators $F_{c}=0.575$ and $F_{i}=0.61$, it was established that the circular potential of the Kalundborg Symbiosis ecosystem is realized quite productively, but not in full. From a managerial point of view, it is advisable for actors to continue working on joint circular projects, improving joint business processes, introducing new technologies and thereby strengthening symbiotic ties within the ecosystem. The integration potential of the Baltic Industrial Symbiosis ecosystem. To further enhance ecosystem integration, it is recommended to increase the integration potential of actors by increasing the number and volume of co-financing of joint international cross-industry projects.

The holistic knowledge of circularity processes provides new information that supports academics, policymakers, government, and individuals with a more appropriate understanding of the conditions 
that help to eliminate the environmental problems faced in society, helping to achieve the country's sustainable development goals.

\section{Limitation and Future Research Directions}

We have developed a novel methodological framework for industrial ecosystem potential assessment with a focus on integration and circular effects. Meanwhile, the proposed approach has some shortcomings and limitations caused by them. The following main limitations should be mentioned: It is not applicable for scenario calculations, labor-intensive approach, high volatility of estimates, problems of specification selection when choosing data sources, high susceptibility to the ranking method and parameter values.

We raise the following questions to be addressed as future lines of research. Firstly, it is necessary to develop conceptual and methodological aspects of the ecosystem's sustainability (innovative, industrial, entrepreneurial, etc.) and classify the risks that arise for each actor involved in the ecosystem.

Secondly, the authors plan to further develop the theory of innovation ecosystems in terms of studying the impact of individual actors, the relationship between them, and the external environment on the stability of the ecosystem as a whole.

Thirdly, it will be necessary to adapt a proposed three-level methodology for assessing potentials for different types of ecosystems depending on the stage of the ecosystem's life cycle.

Finally, it is necessary to validate the theoretical foundations and propose an extended system of indicators for assessing the circular potential of actors in the industrial ecosystem. Currently, most authors use the same indicators to assess circularity for measuring sustainability. This makes it difficult to reveal the contribution of circular processes to the achievement of environmental/green goals.

Author Contributions: T.T.: conceptualization, methodology, formal analysis, supervision. N.S.: writing-original draft preparation, collected data, data validation, performed the first data analyses; L.G.: conceptualization, elaborated the literature review, supervision, data validation, writing-original draft preparation. All authors have read and agreed to the published version of the manuscript.

Funding: This research was funded by the RFBR grant No. 20-010-00470.

Acknowledgments: We acknowledge the support given by anonymous reviewers.

Conflicts of Interest: The authors declare no conflict of interest.

\section{References}

1. Fischer, A.; Pascucci, S. Institutional incentives in circular economy transition: The case of material use in the Dutch textile industry. J. Clean. Prod. 2017, 155, 17-32. [CrossRef]

2. Fedotkina, O.; Gorbashko, E.; Vatolkina, N. Circular economy in Russia: Drivers and barriers for waste management development. Sustainability 2019, 11, 5837. [CrossRef]

3. Sverko Grdic, Z.; Krstinic Nizic, M.; Rudan, E. Circular economy concept in the context of economic development in EU countries. Sustainability 2020, 12, 3060. [CrossRef]

4. Ghisellini, P.; Cialani, C.; Ulgiati, S. A review on circular economy: The expected transition to a balanced interplay of environmental and economic systems. J. Clean. Prod. 2016, 114, 11-32. [CrossRef]

5. Bocken, N.; De Pauw, I.; Bakker, C.; Van Der Grinten, B. Product design and business model strategies for a circular economy. J. Ind. Prod. Eng. 2016, 33, 308-320. [CrossRef]

6. Lewandowski, M. Designing the business models for circular economy-Towards the conceptual framework. Sustainability 2016, 8, 43. [CrossRef]

7. Farber, S.; Costanza, R.; Childers, D.L.; Erickson, J.; Gross, K.; Grove, M.; Hopkinson, C.S.; Kahn, J.; Pincetl, S.; Troy, A.; et al. Linking ecology and economics for ecosystem management. Bioscience 2006, 56, 121-133. [CrossRef]

8. Gladek, E. The Seven Pillars of the Circular Economy. Available online: https://www.greenbiz.com/article/7pillars-circular-economy (accessed on 15 May 2020).

9. Bruel, A.; Kronenberg, J.; Troussier, N.; Guillaume, B. Linking industrial ecology and ecological economics: A theoretical and empirical foundation for the circular economy. J. Ind. Ecol. 2019, 23, 12-21. [CrossRef] 
10. Erkman, S. Industrial ecology: An historical view. J. Clean. Prod. 1997, 5, 1-10. [CrossRef]

11. Isenmann, R. Setting the boundaries and highlighting the scientific profile of industrial ecology. Inf. Technol. Env. Eng. 2008, 1, 32-39.

12. Jollands, N. Concepts of efficiency in ecological economics: Sisyphus and the decision maker. Ecol. Econ. 2006, 56, 359-372. [CrossRef]

13. Kallis, G.; Kerschner, C.; Martinez-Alier, J. The economics of degrowth. Ecol. Econ. 2012, 84, $172-180$. [CrossRef]

14. Stahel, W.R. The Performance Economy; Springer: Berlin/Heidelberg, Germany, 2010.

15. Lovins, A.B.; Lovins, L.H.; Hawken, P. A road map for natural capitalism. Harv. Bus. Rev. 1999, 77, $218-234$. [CrossRef]

16. Mont, O. Clarifying the concept of product-service system. J. Clean. Prod. 2002, 10, 237-245. [CrossRef]

17. Pauli, G.A. The Blue Economy: 10 Years, 100 Innovations, 100 Million Jobs; Paradigm Publications: Boulder, CO, USA, 2010.

18. Borrello, M.; Pascucci, S.; Cembalo, L. Three propositions to unify circular economy research: A review. Sustainability 2020, 12, 4069. [CrossRef]

19. Ayres, R.U. Industrial metabolism: Work in progress. Theory Implement. Econ. Models Sustain. Dev. 1998, 15, 195-228. [CrossRef]

20. Frosch, R.A.; Gallopoulos, N.E. Strategies for manufacturing. Sci. Am. 1989, 261, 144-152. [CrossRef]

21. $\mathrm{Xu}, \mathrm{F}$.J. The studies of the concept plan of the fengcheng industrial park towards the circular economy. Adv. Mater. Res. 2012, 598, 220-223. [CrossRef]

22. Granstrand, O.; Holgersson, M. Innovation ecosystems: A conceptual review and a new definition. Technovation 2020, 90-91. [CrossRef]

23. Wareham, J.; Fox, P.; Lluís Cano Giner, J. Technology ecosystem governance. Organ. Sci. 2014, 25, 1195-1215. [CrossRef]

24. Carayannis, E.G.; Campbell, D.F.J. Knowledge Creation, Diffusion, and Use in Innovation Networks and Knowledge Clusters: A Comparative Systems Approach Across the United States, Europe, and Asia; Praeger Publishers: Westport, CT, USA, 2016; p. 253.

25. Jackson, D.J. What is an Innovation Ecosystem? National Science Foundation: Arlington, VA, USA, 2011; pp. 1-11.

26. Kleyner, G.B. Industrial ecosystems: A look into the future. J. Russ. Econ. Revival 2018, 3, 53-62.

27. Shmeleva, N. Innovation ecosystems in metallurgical industry: Evolution, measurements and trends. In Proceedings of the 19th International Multidisciplinary Scientific GEO Conference SGEM 2019, Sofia, Bulgaria, 30 June-6 July 2019; Volume 18, pp. 1138-1147.

28. Vasin, S.; Gamidullaeva, L.; Tolstykh, T.; Rostovskaya, T.; Skorobogatova, V. From innovation system through institutional transformation to digital innovation ecosystem. In Proceedings of the 31st International Business Information Management Association Conference, Milan, Italy, 25-26 April 2018; pp. 4620-4633.

29. Yeo, Z.; Masi, D.; Low, J.; Ng, Y.; Tan, P.; Barnes, S. Tools for promoting industrial symbiosis: A systematic review. J. Ind. Ecol. 2019, 23, 1087-1108. [CrossRef]

30. Dorokhina, E.Y.U. Industrial and eco-industrial parks as a means for the resolution of regional conflicts in the use of natural resources. Probl. Reg. Ecol. 2018, 2, 113-118. [CrossRef]

31. Park, J.; Park, J.M.; Park, H.S. Scaling-up of industrial symbiosis in the Korean national eco-industrial park program: Examining its evolution over the 10 years between 2005-2014. J. Ind. Ecol. 2019, 23, 197-207. [CrossRef]

32. Association of Industrial Parks of Russia. Industrial Parks of Russia. Industry review. 2019. Available online: https://indparks.ru/en/ (accessed on 10 March 2020).

33. United Nations Industrial Development Organization (UNIDO); World Bank Group; GIZ. 2017 An International Framework for Eco-Industrial Parks. Available online: https://doi.org/10.1596/29110 (accessed on 12 April 2020).

34. United Nations Industrial Development Organization (UNIDO). Eco-Industrial Parks-Achievements and Key Insights from the Global RECP Programme; UNIDO: Vienna, Austria, 2019.

35. Chertow, M.R. Uncovering industrial symbiosis. J. Ind. Ecol. 2007, 1, 11-30.

36. Ayres, R.U.; Simonis, U.E. (Eds.) Industrial Metabolism-Restructuring for Sustainable Development; United Nations University Press: Tokyo, Japan; New York, NY, USA; Paris, France, 1994. 
37. Kytzia, S.; Nathani, C. Bridging the gap to economic analysis: Economic tools for industrial ecology. Prog. Ind. Ecol. 2004, 1, 143-144. [CrossRef]

38. Ellen MacArthur Foundation. Towards a Circular Economy: Business Rationale for an Accelerated Transition, Greener Management International; Ellen MacArthur Foundation: Cowes, UK, 2015.

39. Hatziiordanou, L.; Fitoka, E.; Hadjicharalampous, E. Indicators for mapping and assessment of ecosystem condition and of the ecosystem service habitat maintenance in support of the EU Biodiversity Strategy to 2020. One Ecosyst. J. 2019, 4, 71-87. [CrossRef]

40. European Commission Report, 2014. Available online: https://ec.europa.eu/environment/nature/knowledge/ ecosystem_assessment (accessed on 24 March 2020).

41. Mil'skaya, E.; Bychkova, A. Analysis and evaluation of innovation and investment activities potential of economic entities (for example, the Northwestern Federal District). St. Petersburg State Polytechn. Univ. J. Econ. 2017, 2, 45-53.

42. Nauwelaers, C.; Reid, A. Methodologies for the evaluation of regional innovation potential. Sci. J. 1995, 34, 497-511. [CrossRef]

43. Gamidullaeva, L.A.; Vasin, S.M.; Wise, N. Increasing small- and medium-enterprise contribution to local and regional economic growth by assessing the institutional environment. J. Small Bus. Enterp. Dev. 2020, 27, 259-280. [CrossRef]

44. Aluftekin, N.; Tas, A. Assessment of cluster potential and decision making criterion in the textile and apparel sector using the analytic hierarchy process (AHP). Afr. J. Bus. Manag. 2011, 5, 9125-9136.

45. Danielsson, S.; Møller, P.; Randers, L. Modelling $\mathrm{CO}_{2}$ savings and economic benefits for the Kalundborg symbiosis. Available online: http:/www.symbiosis.dk/wp-content/uploads/2018/06/ KalundborgSymbiosisPaperLCA2018-06.pdf (accessed on 12 April 2020).

46. Kalundborg Symbiosis: Six Decades of a Circular Approach to Production. Available online: https:/circulareconomy.europa.eu/platform/en/good-practices/kalundborg-symbiosis-six-decadescircular-approach-production (accessed on 2 April 2020).

47. Ehrenfeld, J.; Gertler, N. The Evolution of Interdependence at Kalundborg. J. Ind. Ecol. 1997, 1, 67-79. [CrossRef]

48. Interreg Baltic Sea Region 2014-2020. Available online: https://projects.interreg-baltic.eu/projects/bis-186.html (accessed on 5 April 2020).

49. Baltic Industrial Symbiosis. Available online: https://symbiosecenter.dk/project/bis/ (accessed on 2 April 2020).

50. BIS Baltic Industrial Symbiosis. Available online: http://tyreman.ru/bis (accessed on 4 April 2020). 